\title{
A Humanização do SUS como uma política do comum
}

Este suplemento da revista Interface - Comunicação, Saúde, Educação é resultado de um conjunto de esforços da Política Nacional de Humanização (PNH) para sistematizar e socializar reflexões em torno do tema da humanização da saúde, notadamente da produção realizada no Seminário "Humanização do SUS em debate", realizado nos dias 25 e 26 de Junho de 2008, em Vila Velha, ES.

O diálogo, como opção política e como método de incluir sujeitos e coletivos, imprime à PNH mudanças e, assim, ela vai se alterando, acolhendo e incorporando novos elementos. Incluir não pode ser um discurso da moda, e o desafio é a sua afirmação como uma prática política. É por esta razão que, nestes cinco anos de existência da Política de Humanização, permaneceu a convicção de que não se constrói e fortalece uma política pública sem a inclusão de sujeitos, sujeitos no plural, sujeitos no singular. Este fascículo da revista Interface, plural e heterogênea, reflete este processo inclusivo.

O SUS, como aposta ético-política, é um instrumento de luta, no campo da saúde, em relação às formas de autoritarismo e às práticas de captura da vida no capitalismo contemporâneo. Levar à frente tal luta pela democratização institucional das práticas de produção de saúde exige o compromisso dos diferentes atores envolvidos neste processo. Daí a importância de colocarmos, lado a lado, trabalhadores, gestores e usuários nos momentos de planejamento, execução e avaliação das práticas de saúde.

O SUS como uma política pública de saúde busca garantir o direito à saúde. Política pública que, na nossa aposta, não se confunde com as políticas de governo. Por outro lado, lutamos para que seja uma Política assumida pelo Estado, já que talvez aí esteja alguma possibilidade de ela continuar existindo mesmo quando não existir como política de governo. Eis o dilema: queremos o público porque queremos fortalecer o plano do coletivo, o plano comum, mas não queremos que o Estado e os governos se tornem única expressão do coletivo, o que significaria a privatização das políticas.

Temos vivido este debate, uma discussão conceitual-política, "mas também uma maneira de nos debater, tentando não afogar", buscando a institucionalidade da política de humanização do SUS, mas procurando escapar da institucionalização que poderia nos deixar esvaziados de força instituinte. Reafirmamos a PNH como política transversalizadora, uma vez que argúi as práticas de verticalização e fragmentação. Assim, seu principio, seu caráter transversalizador, busca argui-la todo o tempo para diminuir o risco da sua própria institucionalização.

Esta publicação se inscreve neste movimento e opção ético-política: espaço de apresentação, de afirmação, mas também de arguição, que impõe movimento de reflexão, de reposicionamentos. Este Suplemento é um instrumento de análise e de afirmação da Política de Humanização como estratégia de aprimoramento de nossa experiência civilizatória no campo da saúde.

Alguns artigos, encomendados pela coordenação do evento, são assinados por pesquisadores que, como propositores do Seminário, apresentam questões para um debate com os pesquisadores da área, ampliando a interlocução dos formuladores da PNH com a comunidade acadêmica. Buscaram problematizar as práticas de saúde com base no tema da humanização do SUS. Outros foram produzidos por pesquisadores que, na função de debatedores no Seminário, são consultores da PNH e pretenderam fazer uma discussão da proposição feita para cada tema-eixo. Temos, também, artigos de pesquisadores que participaram do evento e, com sua diversidade de abordagens, enriquecem esse debate; e textos produzidos nos cursos promovidos pela PNH que apresentam questões importantes para o debate em pauta.

Os artigos reunidos neste número da revista têm o sabor das práticas e de reflexões que afirmam permanentemente uma forma criadora de pesquisar e trabalhar no campo da saúde. Vislumbramos, com esses textos, a possibilidade de ampliar o debate no âmbito da produção acadêmica no campo da Saúde Coletiva, de forma a analisar os problemas enfrentados no cotidiano dos serviços de saúde em sua complexidade, e construir estratégias para superá-los. Entre os aspectos destacados nos textos aqui apresentados, está a necessidade de se envolver a comunidade acadêmica nessa discussão e produzir práticas, fruto de um debate ampliado, de forma a contemplar as múltiplas variáveis que compõem o processo de trabalho nos serviços de saúde e nas universidades.

Dário Frederico Pasche, Eduardo Passos e Maria Elizabeth Barros de Barros Ministério da Saúde, Política Nacional de Humanização 